\title{
Reaction of Sedum spurium „Purpurteppich" Exposed to Thermal and Hydric Stress
}

\author{
Adrian ZAHARIA ${ }^{1}$, Denisa JUCAN ${ }^{1 *}$, Erzsebet BUTA ${ }^{1}$ \\ ${ }^{1}$ Departament of Ornamental plants, University of Agricultural Sciences and Veterinary Medicine \\ Cluj-Napoca, Romania \\ *)Corresponding author, e-mail: denisa.jucan@usamvcluj.ro
}

BulletinUASVM Horticulture 73(2) / 2016

Print ISSN 1843-5254, Electronic ISSN 1843-5394

DOI:10.15835/buasvmcn-hort:12365

\begin{abstract}
A cultivar of sedum was used in this experience. Stems were harvested from normally developed plants and were exposed to extreme conditions of temperature and draught. Results obtained show that the plants lost significant quantities of water by physiological processes from one day to another, their weight varying from 16.8 $\mathrm{g}$ to $47.9 \mathrm{~g}$.
\end{abstract}

Keywords: dehydration, stalks, temperature, water loss.

\section{Introduction}

Sedum species are appreciated for their ability to grow in harshest parts of the gardens, they are easily facing dryness of summer, while most other plants less resistant to these conditions wither and die (Tan and Sia, 2005).

On green roofs, environmental conditions are extreme, so xerophytic plants, like Sedum, are perfect for these green areas because sedums are from physiological and morphological point of view, adapted to drought (Durhman snd Rowe, 2006).

Succulent plants are well-adapted to the conditions often found on extensive green roofs because of their ability to limit transpiration and store excess water (Getter and Rowe, 2008).

\section{Aims and Objectives}

The research aimed to find if the vegetal material is appropriate for green roofs arrangements and the objective was to see how many days can survive broken stems on these extreme conditions.

\section{Material and Methods}

The experience was developed in the didactical field of the Floriculture department of UASVM Cluj-Napoca. There were used sterile stalks of Sedum spurium cv. Purpurteppich, harvested from 30 plants grown in outdoor ecological conditions. The biological material was exposed to height temperature $\left(30-55^{\circ} \mathrm{C}\right)$ and lack of water for 10 days. The plants were installed on a concrete platform of $1 \mathrm{~m}^{2}$, exposed to full sun. The temperature was measured at the level of the plants where, due to concrete and sunny exposure, the temperature is higher than the air temperature.

The partial weight is reflecting the differences of weight from one day to day. The values of cumulative weight were obtained by calculating the differences between the first day and the second, first day minus the third, first day minus the $4^{\text {th }}$, etc. (for example: Due to dehydration, during the 10 days of exposure to stress conditions, the weight decreased by $47.9 \mathrm{~g}$ ).

\section{Results}

Analyzing the results from table 1, regarding the modifications of the weight of stalks exposed to high temperature and lack of water, can be noticed that in the first days, the weight of the sterile stalks is suddenly decreasing, while, in the next days, the loss of water is lower than in the first days, reaching to only 0-2 grams/day. Also, by reporting the losses of water (partial and cumulative) to 


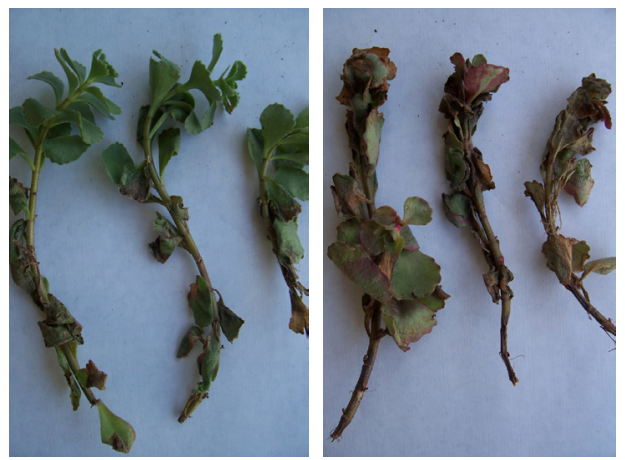

Fig. 1. Stalks of Sedum spurium Purputeppich exposed to extreme conditions

Tab. 1. Weight of Sedum spurium Purputeppich stalks during the 10 days of extreme conditions exposure

\begin{tabular}{cccc}
\hline Day & Stalk weight $(\mathrm{g})$ & Partial weight $(\mathrm{g})$ & Cumulative weight $(\mathrm{g})$ \\
\hline $1^{\text {st }}$ & $56.03^{\mathrm{a}}$ & - & - \\
\hline $2^{\text {nd }}$ & $39.23^{\mathrm{b}}$ & $16.80^{\mathrm{g}}$ & $16.80^{\mathrm{h}}$ \\
\hline $3^{\text {rd }}$ & $31.03^{\mathrm{c}}$ & $8.20^{\mathrm{f}}$ & $25.00^{\mathrm{g}}$ \\
\hline $4^{\text {th }}$ & $21.23^{\mathrm{d}}$ & $9.80^{\mathrm{e}}$ & $34.80^{\mathrm{f}}$ \\
\hline $5^{\text {th }}$ & $17.07^{\mathrm{e}}$ & $4.16^{\mathrm{d}}$ & $38.97^{\mathrm{e}}$ \\
\hline $6^{\text {th }}$ & $14.87^{\mathrm{f}}$ & $2.20^{\mathrm{c}}$ & $41.16^{\mathrm{d}}$ \\
\hline $7^{\text {th }}$ & $12.80^{\mathrm{g}}$ & $2.07^{\mathrm{bc}}$ & $43.23^{\mathrm{c}}$ \\
\hline $8^{\text {th }}$ & $10.37^{\mathrm{h}}$ & $2.43^{\mathrm{b}}$ & $45.66^{\mathrm{b}}$ \\
\hline $9^{\text {th }}$ & $8.30^{\mathrm{i}}$ & $2.07^{\mathrm{bc}}$ & $47.73^{\mathrm{a}}$ \\
\hline 10 & $8.13^{\mathrm{i}}$ & $0.17^{\mathrm{a}}$ & $47.90^{\mathrm{a}}$ \\
\hline Note: Different letters between values denote significant differences (Duncan test, DS: $0.33-0.38)$.
\end{tabular}

fresh mass of plants of previous determination show some growth. This can be explained by the variability of environmental factors from one day to another. The amounts of water lost due to exposure of stalks to hydric and thermal stress are statistically significant from one day to another.

Regarding the partial weight of the 30 analyzed stalks, the majority of the differences of water loss from one day to another are significantly different. In the first 5 days of the experience, the differences between the weights of the stalks are statistically different. But, even the numbers are different, the quantity of water lost by dehydration in the $5^{\text {th }}$ day $(2.02 \mathrm{~g})$, is equal to the quantity of water lost in the $7^{\text {th }}(2.07 \mathrm{~g})$ and $9(2.07 \mathrm{~g})$ day, from a statistical point of view. In the same time, in day 8 were lost $2.43 \mathrm{~g}$ of water, which value is also statistically equal to those registered in days $5^{\text {th }}$ and $8^{\text {th }}$.

The weight of the plants decreased significantly comparing to the first day of the experiment. In the $9^{\text {th }}$ and 10 day, even the values are different, and the quantity of water loss in these days is also statistically ensured, the cumulative weight of the plants the same from statistical point of view. This means that, comparing to the first day, in the last two days, the plants lost almost $48 \mathrm{~g}$ by physiological processes.

Based on observations on the plants, the first and most affected are the leaves in the reverse order of their emergence (Fig.1). The leaves at the base of the stems are the oldest and they are the first affected. They totally lose turgor, wither and they finally dry out. But stems, buds and leaves of apical part of the plant proved to be very strong.

\section{Conclusion}

After 10 days, the experiment was stopped because the plants more than $50 \%$ of the stalks were appreciated as being too weak to be able to emerge new roots. In conclusion, the studied cultivar (Sedum spurium cv. Purpurteppich) cannot survive more than 10 days on extreme dry and very high temperature $\left(30-55^{\circ} \mathrm{C}\right)$. But, after 8-9 days, some of the stems, in the appropriate 
conditions of moisture, formed in the bud area, new shoots that have developed as normally.

\section{REFERENCES}

1. Durhman AK, Rowe DB (2006). Effect of watering regimen on chlorophyll fluorescence and growth of selected green roof plant taxa. HortScience 41(7): 1623-1628.
2. Getter K.L, Rowe DB (2008). Selecting plants for extensive green roofs in the United States. Extension Bulletin E-3047:1-9. Michigan State University.

3. Tan PY, Sia A (2005). A pilot green roof research project in Singapore, Greening Rooftops for Sustainable Communities Conference, Washington DC, USA, 4-6 May 2005. 